Praxis International Journal of Social Science and Literature

Impact Factor: SJIF 2020 = 5.754 ISSN: 2581-6675

Volume - 4, Issue - 7, July - 2021

Website: www.pijssl.com, E-mail: editor.pijssl@gmail.com

\title{
The Relevance of Gandhi in the Age of Globalisation
}

\section{Dr. Uma Shankar}

Associate Professor, Department of Political Science, Zakir Husain Delhi College, University of Delhi

\begin{abstract}
The relevance of Gandhian ideas and his technique of satyagraha in resolving global problems is even greater today. The economic disparity, social divisions, ecological catastrophe and growing social intolerance are global challenges in the age of capitalist and technological globalisation. Globalisation as an economic model with neo- liberal ideology is inconsistent with Gandhian economic and political philosophy. Globalisation per se does not seem to be not be reversible as the hegemony of the global capital is deeply entrenched. However, its malaise can be better managed with Gandhian prescriptions.

Gandhi stands for pursuit of truth, incessant enquiry, nonviolence, human values, dignity of labour, and respect for the plurality of views, economic and political decentralisation with substantial decrease in the power of the state. Gandhian vision stands for mobilisation of the people's power through nonviolent active participation against all kinds of injustices and making the political power accountable in the service of the society. Gandhi had deep faith in the intrinsic goodness of individual human beings and he staunchly believed and demonstrated that truthful and moral means are superior to immoral means in redressing the social and political problems confronting mankind. Gandhian economic and political vision is for a decentralised, just and nonviolent society which is indispensable for spiritual and moral upliftment of individual human beings. Gandhian prescriptions are for common masses and practical. It only requires pursuit of truthful and moral means without any hatred and ill will for anyone in the struggle against domination and injustice.
\end{abstract}

Keywords: Satyagraha, Ahimsa, Dharna, Hindu, Inter-faith, Decentralisation, Moksha, Spiritual

\section{Introduction}

Gandhi has become synonymous with a world view, economic and political philosophy and a strategy of political mobilisation of the masses against injustice and tyranny. Mohan Das Karamchand Gandhi was an ordinary mortal but owing to his pro- people ideas, truthfulness and successful adoption of satyagraha as a technique of mass mobilisation in the anti-imperial struggle became its spiritual and political guide.He combined the anti - British national movement led by the Indian National Congress with his constructive programs for moral and social awakening of the Indian people subjugated under colonial rule

Gandhi did not use philosophical methods in the Western traditions to convey his ideas rather he made his actions as the message of his economic and political ideas. He often said that his life is a message. He lived a life with unity in. mind, words and deeds. Scholars and political thinkers have been trying to decode Gandhian messages and actions into a political philosophy. The present research article is an humble attempt to explain Gandhian world view, his doctrine of Satya and Ahimsa and technique of 
satyagraha in the context of his relevance in the contemporary globalising world.

Globalisation has affected all walks of life in all nations and regions of the world and will have decisive and irreversible effects on the life on this planet. Some of its effects are lauded while some other effects are having alarming signs on the future of human civilisation. Human kind is standing at the crossroads and there is no clear blueprint about the future of human civilisation in the age of globalisation nor there is any roadmap regarding appropriate responses to the unbridled global push for neoliberal capitalism. Gandhian world view warrants due consideration in search for solution to the problems resulting from globalisation.

\section{Gandhi and Globalisation}

The life and ideas of M.K. Gandhi are very much debatable in the present age of globalisation. Some of his ideas are utopia and unrealistic while some other ideas are quite appreciated by both the protagonists and opponents of globalisation. Whatever it may be the issues that globalisation have raised were very much in the mind of Gandhi and he had expressed his views on them frankly with a great degree of foresight. Gandhi was per se not opposed to globalisation as "he himself was the product of globalisation. He was exposed to public life and its challenges in the UK and South Africa and was deeply influenced by the ideas of Jesus, Tolstoy, Thoreau and Ruskin".1

He did understand the advantages and disadvantages of global expansion of capitalism which is the driving force behind globalisation. He opined that global integration per se was not evil but to believe that everything Western was superior was not the correct stand to take. He did not perceive any threat to our culture due to globalisation but he did believe that it would lead to environmental hazards and consumerism- both of which have proved correct. He favored dialogue among cultures. "I do not want my house to be walled on all sides and my windows to be stuffed. I want the cultures of all lands to be blown about my house as freely as possible but I refuse to be blown off my feet by any."2

Globalisation per se is not wrong as it has the potential through technology and communications network to transcend the barriers of time and distance and thus bringing people closer and deeply connected to each other. Globalisation would expose different cultures and belief systems to each other and thus has the potential to facilitate dialogue among cultures and Peoples. Though Gandhi was not much perturbed about the cultural challenges of the Western dominated globalisation but he was deeply concerned about its political, economic and environmental consequences on the freedom, livelihood and ecological health affecting the humanity as a whole.

\section{Criticism of the Industrial Western Civilisation}

In his famous work Hind Swaraj Gandhi is known for his critique of modern civilisation based on materialistic,

consumerist, profit centric and machine- based capitalist economy. Gandhi formalized his world view and his approach to economic and political organization in the context of anti- imperial nationalist movement. Gandhi's world view centered on spiritual and moral revitalization of individual man and building a society founded on truth, nonviolence, tolerance love and compassion. Gan dhi viewed the goals of life in terms of spiritual journey in search of truth and inner fulfilment of soul of man. For Gandhi truth is not absolute rather there are multiple truths to be realized through experience. Love and tolerance for all should characterize the search for truth. He was opposed to any homogenised view of Indian society and appreciated its diversity. "Gandhi looked at the human problem in a holistic way. Economic was only one aspect, and he was equally concerned with the social, political, cultural and the spiritual"3

Gurudev Ravindranath Tagore commented; 
"We have for over a century been dragged by the prosperous West behind its chariot, choked by the dust, deafened by the noise, humbled by our own helplessness and overwhelmed by the speed. We agreed to acknowledge that this chariot-drive was progress, and the progress was civilisation. If we ever ventured to ask 'progress towards what and progress for whom', it was considered to be peculiarly and ridiculously oriental to entertain such ideas about the absoluteness of progress. Of late a voice (Gandhi) has come to us to take count not only of the scientific perfection of the chariot but of the depth of the ditches lying in its path"4

Economic and

political

organisation should be able to provide conducive environment for spiritual and moral revitalisation of individual with integrity of body, mind and soul. Gandhi viewed the greed, profit motive and consumerist culture of capitalism injurious to spiritual and moral fulfilment of individuals. He was skeptical of industrial capitalism, which gave rise to exploitative colonial imperialism. He viewed industrial capitalist economy and powerful modern nation- state with great alarm. He regarded concentration of economic and political power as a serious threat to human freedom and his moral spiritual progress. His participation in the anti-colonial nationalist movement was geared towards his dream of realizing an independent India where his vision of a decentralised social, economic and political order of the nation could be realised.

Gandhi's understanding of colonialism during the first half of the 20th century and neoliberal capitalist globalisation of today would stem from his critique of the modern Western civilisation. He rejected Western modernity characterised by machine-driven industrialisation, concentration of economic and political power, rise in inequality and violent mighty power of state. He cherished individual freedom which would not be safe in highly industrialised and monopoly capitalism. He believed that violent bureaucratic machine of state would be a threat to freedom and individual initiative. Gandhi was not a Marxist in his world view and he rejected materialistic conflict centric approach to political and social problems. Gandhi in his spiritual and religious world view had a nostalgia for selfsufficient localized village economy based on need-based economic production and exchange system and a society based on love, cooperation and harmony.

In Gandhi's view spiritual quest for truth and development of moral and spiritual personality is the goal of human life to which political and economic organisation should be supportive of. Gandhi was deeply influenced by the four-fold objectives of Hindu social life as artha (wealth), dharma (morality), kama (reproduction) and moksha (liberation). Moksha refers to spiritual enhancement leading to freedom of the self from all kinds of mental and physical bondage. A pure mind is free from the control of kaam (lust), krodh (anger), lobh (greed), moha (attachment) and ahankar (ego). Individual initiative and freedom have to be preserved at all costs. Since modern profit based industrial economy and mighty violent state are a threat to individual freedom and his spiritual development, Gandhi was averse to the modern atheistic materialistic civilisation. Certainly, Gandhi would have vehemently opposed the present process of globalisation.

Gandhi advocated living in harmony with nature and diverse life systems on the planet. A major part of Gandhi's criticisms towards industrialisation was geared towards preserving India's rich natural resources. As globalisation has progressed, so has the tendency to try and exploit every possible resource in the country to increase the GDP. Rapid deforestation has occurred throughout the developing world and serious environmental hazards are faced by most developing countries today. "Moreover, corporate power has undermined governmental efforts at curbing environmental loss, as the American withdrawal from the Kyoto Protocol vividly depicted. However, conservation processes led by the UN and also at the national and even local level, are gradually gathering speed in the second phase of globalisation, i.e., whereby most of the 
evils of globalisation are now being questioned and checked. Gandhi is the precursor of the modern Green Movement. ${ }^{5}$

Besides massive environmental hazards, the automation technology and finance driven capitalist globalisation is robbing

ordinary individuals of their employment and livelihood. Globalisation has benefited the rich and educated middle classes but impoverished the labour force, farmers and marginalised sections. The rise in inequality within and among nations and the jobless growth of GDP are the ugly inhuman face of industrial and financial globalisation of which Gandhi had warned. Gandhi favours an economic system which provides work to every hand with due recognition to dignity of labour. Economy should not lead to centralisation of economic and political power as it would threaten freedom and livelihood of ordinary men and women.

It is an irony that increase in the power of the global corporate has accompanied the increase in the power and reach of the state as well as the massive build-up of the weapons of mass destruction. States are losing their sovereignty with regard to their pro people welfare activities but becoming stronger as agents of global corporate and multinationals. Gandhi had successfully led the anti- imperialist struggle against the British Empire. Going by his vision and political philosophy he certainly would have launched a powerful peoples' struggle against the present neoliberal global order and its politics.

\section{Vision of a Nonviolent Society}

Gandhi's vision of a nonviolent society with individuals committed to pursuit of truth and spiritual journey towards self- development would be possible where everyone is free from the basic physical needs of food and shelter. The economic system should cultivate dignity of labour and selfemployment. The industrial capitalist economy in a globalised neoliberal economic order does not augur well for Gandhi's dream of an ideal economy and society. The industrial and political elites have simply ignored Gandhi's prescriptions and imposed a cruel and inhuman consumerist economy with no regard for spiritual and moral essence of human species. Gandhi's prescription for a nonviolent society is possible only in the conditions of an egalitarian and just society and the world order where inequality of wealth and power will not threaten individual liberty and livelihood. ${ }^{6}$

MK Gandhi became Mahatma Gandhi due to his innovation of satyagraha as a technique of peaceful incessant resistance to tyranny and injustice which was rooted in his moral conscience. For the ruling economic and political power Gandhi is a moral burden to which they pay lip service only and adopt economic political and political practices against his vision. In India also the successive regimes including the present invoke Gandhi's name to secure popular legitimacy but have adopted policies and practices quite contrary to his beliefs. From the point of view of the people at the periphery Gandhi remains relevant and a ray of hope.

Gandhi is even more relevant in the age of globalisation particularly for organising a mass resistance movement against the evil consequences of industrial and financial globalisation under a rule based international trade regime of World Trade Organisation. Domestic political elites in developing countries are submitting their national sovereignty to invisible Transnational Corporations and it has become even more difficult to identify the political enemy against whom to focus the resistance struggles. Gandhi's spiritual and moral revulsion against statism, modernity and consumerist globalisation does have the potential to provide an ideological focal point of organising peaceful mass movements against the present model of globalisation. Gandhi was a challenge to the mighty British Empire and its economic and political system during the first half of the 20th century and his ideas still can be the focal point of a serious challenge to the present globalising capitalism. 


\section{Satyagraha as a Technique of Resistance}

Satyagraha is the most important and novel contribution of MK Gandhi to the political thought and ever lasting contribution as a means to reform the individual and society. Gandhi believed and demonstrated that mass satyagraha can reform the character and purpose of politics. It is even more relevant as a method of resistance to globalisation in search for an alternative model. Satyagraha means agraha or moral pressure for the sake of truth. Gandhi states; "The world rests on the bedrock of Satya or truth. Asatya meaning untruth also means non-existent; and Satya or truth means that which is. If $u$ ntruth does not so much as exist, its victory is out of question. And truth being that which is, can never be destroyed. This is the doctrine of satyagraha in a nutshell." 7

For Gandhi truth and God are one and the same and the objective of human life is defined in spiritual terms as a search for truth through the path of ahimsa/nonviolence. Pankaj Misra writes "Perhaps his most important contribution to India's struggle for independence was his spiritual leadership and his consequent influence over the mass of India's population. All his life he held two fundamental principles, a belief in Ahimsa, or nonviolence and the concept of Satya or Truth". Gandhi said in his Autobiography "My uniform experience has convinced me that there is no other God than Truth... and the only means for the realisation of Truth is Ahimsa." 8

Ahimsa is in simple terms love for everyone including the opponent. It can be a way to resist injustice or tyranny without hating the tyrant. The political action inspired by truth and nonviolence will strengthen the moral consciousness of individuals and establish moral foundations of public life. A political order and society with fragile moral foundations and devoid of love and compassion would be the worst form of injustice and tyranny. Gandhi had unflinching faith in the ultimate victory of truth as truth (morally right / pure consciousness) itself is God.

$$
\text { Anil Ojha has }
$$

explained, "The

achievement of political and moral ends through Ahimsais what Gandhi calls satyagraha.
For Gandhi satyagraha is truth force or nonviolent action which is not passive or sullen. It calls for courage, strength of character and positive contribution to a righteous cause. Gandhi's doctrine of nonviolence is not absolute. In some circumstances, he thinks, it might be better to choose violence than to submit to injustice"9

Unshakable faith in truth and nonviolence forms the core of Gandhi's philosophy of life and satyagraha is the form of political action particularly in the context of active resistance to injustice. He firmly believed that only moral means can lead to realisation of goals of political life on a sustainable basis. Pursuit of truth and nonviolence will strengthen moral and spiritual foundations of individual and society. Since Gandhi was primarily concerned with moral and spiritual reforms of individual and society, he was averse to the western notions of all powerful intrusive and coercive state power. Since Niccolo Machiavelli and Thomas Hobbes a notion of coercive sovereign state power separate from religion and morality engaged in the service of rising capitalism had developed in the Western thought, Gandhi's political vision is a clear departure from the dominant Western statist tradition.

After the failure of mutiny of 1857 at the hands of a powerful coercive state apparatus of the British, a sense of disillusion and disappointment had developed in the minds of colonial subject masses in India. Gandhian method of satyagraha suited to organise the passive fatalistic masses into active nonviolent resistance to the mighty violent imperial power. The successful Quit India movement of 1942 demonstrated the moral power of the suffering masses before the violent state power of the British Empire. Gandhi's tactics of satyagraha proved effective then and it can prove effective even today particularly when the state power in the service of global capitalism is more violent with rapidly increasing inequality, inequality and environmental degradation.

Gandhi was opposed to industrial capitalism but not to the institution of private property. He did not favour using coercive 
power of the state to redistribute resources and wealth. On ideological plane he does not favour state-led economic and social transformation because he believed that any social and political change without the spirit of Satya and Ahimsa would not be sustainable. Any social and economic transformation must be founded on moral and spiritual strength and state power in the absence of a morally strong society cannot bring durable and just social political order. Gandhi favoured trusteeship where the rich would voluntarily render their wealth in the service of the people. The trusteeship would inculcate a sense of moral consciousness both among the rich and poor and thus arouse harmony and unity in society.

\section{Critique of Capitalism, Communism and State Power}

It would not be fair to judge Gandhi for his views on ideology and functions of state as he was opposed to increase in the functions of state and its interference in the life of individual and community. He regarded the modern violent state and capitalist industrial economy as obstacles to individuals' moral and spiritual progress. He was convinced that no matter how a state may have progressive ideology, in the absence of morally strong individuals and a society founded on moral norms of love, tolerance and compassion no just society is possible. Gandhi did not have much faith in the efficacy of reforms at the behest of state power. Only a life founded on search for truth through non -violence and love for all can bring happiness and justice both in the individual and society,

According to Gandhi, political power means capacity to regulate the life of the nation through its genuinely elected representatives. In course of time, it is expected that the national life would become so perfect that it will be selfregulating. But till the perfect state of statelessness is arrived as Gandhi suggested the reorganization of existing political system on the basis of non-violence and decentralization. Gandhi was against increasing role of the government in regulation and control over society.
He believed that the society would be just not only when it is casteless and classless but also when it is stateless. He on the face value believed in the communist ideal of a society based on classless and stateless community life but he totally rejected Marxist materialistic and dialectical conflict -based world view. Owing to his complete aversion of state power he rejected both capitalist and socialist models of economy. He said, "I look up on an increase in the power of the state with the greatest fear because, while apparently doing well by minimizing exploitation, it does the greatest harm to mankind by destroying individuality, which lies at the root of all progress." 10

To Gandhi centralisation of power was a sin and synonymous with violence. He, therefore, wanted a democratic government based on nonviolence and decentralisation of power where man is supreme and the state is only a servant. He called it 'Ram Rajya'. Here Ram refers to highest spiritual and moral heights of Maryada Purushottam and he was completely against exclusivist majoritarian Hindu religious politics. He believed in spiritual message of love and compassion as the basis of all religions. $\mathrm{He}$ was not opposed to technological and material progress per se but it must not lead to increase in inequality and exploitation of man by man. Spiritual and moral growth of individual should be the bedrock of any economic and social organisation and any religious belief system.

\section{Gandhian Economic Model}

Gandhi was not an academic economist and his economic vision for the Indian people was very practical geared to fulfil the basic needs of everyone. His vision of economy was not centered on production and consumption of goods. In this respect "Gandhi was very much infatuated by Ruskin's heterodox doctrine that the wealth of a nation consisted, not in its production and consumption of gods, but in its people His economic philosophy was mainly concerned with individual dignity and welfare of the poor people. Gandhi's stress on individual liberty includes a sense of responsibility towards oneself, to 
others to society and perhaps to the world beyond". 11

Economic life should be such which builds character of individual and elevates moral and spiritual fulfilment of man. He regarded the dignity of labour with economic independence and decentralisation of wealth as essential for building spiritual and moral personality of individual. He was opposed to capital- intensive industrialism as it leads to economic inequality and is not employment intensive. Here Gandhi favours an economic model which resembles Marxian concept of classless communist society which can ensure 'From each according to his capacity and to each according to his need.' Marx had regarded capitalist system as the cause of alienation leading to separation of man's self from his species. Gandhi also believes that capitalism would lead to concentration of economic and political power and rob the man and society of its moral virtues.

The difference is Marx sought solution in revolutionary communism and the mighty power of socialist state but Gandhi sought it in pre-capitalist small and cottage industries with village or local self- sufficiency with little dependence on goods produced from outside. Marx had provided a model of socialist revolution as a cure for the ills of industrial capitalist economy and Gandhi is providing an economic model of pre-capitalist economic system with spiritual and moral enrichment of man where technology, capital and greed would not enslave and impoverish man. Machine and heavy industry may be useful only where it is absolutely indispensable and which cannot be done by small scale industries. Economic system must not be allowed to replace human labour force and increase inequality and unemployment.

\section{Global Relevance of Gandhi}

Economic model which generates work/ employment for every hand is the centre piece of Gandhian economic vision. Here one can find the relevance of employment centric Gandhian economics as present-day capitalist welfare economists favour subsidy or cash transfer to the poor who are unable to get employment. Gandhi would have favoured employment generating economy instead of present automation technology and capital-intensive economy which are dependent on cash transfer like schemes for stimulating consumption. The mantra of an economy should be that capital, machine and technology should assist man and not replace human work force.

The dangers posed by capitalist globalisation in the form of consumerism, inequality, poverty and employment, environmental and climate change, pervasive decline in moral fabric, extremism, intolerance and aggressive nationalism do compel us to have a relook into Gandhian thought and adjust the economic and social policies suitably. The political establishment, monopoly capital and global multinational corporations would resist all attempts to resurrect Gandhian precepts and his politics but the people have no choice except to organise peaceful resistance for a humane and just world.

For Gandhi Satyagraha meaning nonviolent direct action was to arouse the conscience of the oppressors and invigorate their victims with a sense of moral agency. "Gandhi's unique mode of defiance, Reinhold Niebuhr observed as early as 1932, not only works to rob the opponent of the moral conceit by which he identifies his interests with the peace and order of society. It also purges the victim's resentment of the egoistic element producing a purer vehicle of justice."12. However, Niebuhr was critical of the efficacy of the satyagraha upon the mighty and the rich. He continued to see nonviolence as a better alternative but by no means ideal.

According to Ramchandra Guha, "The most important and influential of Gandhi's ideas is one we affirm every day without recognising it comes from him- our constitutional commitment to linguistic pluralism and diversity. Four aspects of Gandhi's legacy remain relevant, not just to India, but to the world. First, nonviolent resistance to 
unjust laws and / or authoritarian governments. Second, the promotion of inter-faith understanding and religious tolerance. Third, an economic model that does not rape or pillage nature. Fourth, courtesy in public debate and transparency in one's public dealings." 13

In the Indian context in the anti-imperial struggle satyagraha as a political method did play a great role in mass mobilisation. The pursuit of satyagraha is a courageous act and Gandhi demonstrated it as an effective method of mass mobilisation as well as a means of realising just and morally correct objectives. It helps in self transformation of the satyagrahis well as impresses upon the adversary to accede to just and morally correct demands. Gandhi's satyagraha is the most potent method available to humanity to resist all forms of tyranny and exploitation which is also in the spirit of expansion of democracy, peace and harmony within nations and in the global society. Gandhi believed that change brought in by violent means cannot be sustainable.

Gandhian method of passive resistance in itself may not be a panacea for all political and social problems but it certainly is an alternative worth trying. It may not give quick results, which depends upon a variety of factors. However, it will certainly help in building character and soul of an individual. In a democratic society satyagrahal passive resistance has a great deal of significance as it pleads for moral means and facilitates peaceful transformation of society and removal of injustice with popular participation. It gives a great deal of importance to purity of means in order to realise morally justified ends.

\section{Conclusion}

Gandhian economic, social and political ideas are partly relevant in the present globalising world. It may be difficult to manage the modern economies of the world on Gandhian principles. Gandhi articulated an alternative economic-and social order which is not in tune with modern capitalist industrial economy. Neo liberal global capitalism has inherent fault lines but the modern economic and political elites are not prepared to adopt Gandhian prescriptions.

Gandhian vision is relevant as a moral and spiritual force to improve individual and collective life. Truth and non-violence are essential for peace and harmony in the life of both individual and society and provide a moral foundation to liberal democratic political order. Rule of law envisages resolution of social conflicts in a non-violent manner with respect for dissent and plurality of views in a political society. Gandhi's total aversion for mighty state power and opposition to concentration of wealth is inconsistent with globalisation. His concern for environment, human dignity, freedom and advocacy for peaceful methods of social and political change through collective action still make him relevant today.

Gandhi has provided a practical method to arouse moral power of the larger masses to deal with the coercive power of the state machinery and to resist the structures of domination and inequality. Mass Satyagraha can be effective by virtue of fearlessness of the satyagrahis and its capacity to delegitimise the power of the oppressor. Gandhi's message of purity of consciousness and a morally conscious society with free individuals full of compassion, love and tolerance for each other should be the bedrock of economic and political order.

\section{References}

1. Quoted in Jan Oberg in Birla House with Gandhi

cited in Mukherjee, Aruni, Gandhi and

Globalisation mkgandhi.org
2. Nadkarni, M.V. Gandhi and Globalisation in Jayram, N and Rajshekhar,D (edited)Vulnerability and Globalisation: Perspectives and Analyses from India Rawat Publications ,New Delhi p.124 
3. Sudarshan,R. Globalisation and Gandhi at the Dawn of the New Millenium

Cited in Mukherjee, Aruni, Gandhi and

Globalisation mkgandhi.org

4. Mukherjee, Aruni, Gandhi and

Globalisation mkgandhi.org

Quoted in Sudarshan R. Globalisation and

Gandhi at the Dawn of the New Millennium

5. Sudarshan,R.(1998) Globalisation and Gandhi at the Dawn of the New Millennium

Cited in Mukherjee, Aruni, Gandhi and Globalisation mkgandhi.org

6. See Parekh, Bhikhu, Webinar on Gandhi and Swaraj in Ideas

Kumar, Himanshu, www. youtube.com

Gandhi Study Circle, Zakir

Husain Dellhi College. 30 January 2021

7. Gandhi, MK. (1968) Satyagraha in South Africa, part 11 chapter 16 on 'Women in Jail' Ahmedabad Navjivan press, p. 323

8. Misra, Pankaj in Foreword to Gandhi, M.K. An Autobiography or The Story of My Experiments with Truth Penguin 2007, Navjivan Publishing House vol 1, 1927, vol 2,1929

9. Ojha,Anil, The Relevance of Satyagraha as a Weapon of Conflict
Resolution mkgandhi.org_Smiley,

Glenn, How non-violence works mkgandhi.org

10. Shikhare, G.S, Gandhian Economic Order in the New Millenniumwww.mkgandhi.org Gandhi in the New Millennium: Issues and Challenges (2014) Khandwala publishing House

11. Chavan,S.(2013) Economic Ideas of Mahatma Gandhi Indian Stream Research Journal vol.3(9) pp.1

12. Niebuhr, Reinhold, Moral Man and Immoral Society (1932) cited in Mishra, Pankaj, Gandhi for Post-Truth Age

www. newyorker.com magazine 18 October 2018

13. Guha, Ramchandra, On Why Gandhi remains globally relevant $\mathrm{BBC}$ News http;// www.bbc.com/news/world-asia -India25445297

cited in Pandey, Rudresh and Perez Flores, Karina Elizabeth, Gandhian Philosophy of International Relations Paper presented at Gandhi and Contemporary World Proceedings of International Conference, 24-25 February, 2016 Gandhi Study Circle, Zakir Husain Delhi College, University of Delhi p.185 